\title{
BEHAVIOR OF ERADICATING MOSQUITO NESTS AND LARVA INDEX WITH INCIDENCE RATE OF DENGUE INFECTION AT KUPANG CITY \\ Julio CA de Fatima ${ }^{1)}$, Steven ${ }^{2}$,Laura Wihanto ${ }^{3)}$
}

\begin{abstract}
Introduction : Dengue infection occurs at a large scale in Indonesia, especially in Kupang City. The incidence rate of dengue infection in January 2019 was 245 cases and caused 15 deaths. The number of cases and mortality at Kupang City increased in 2019. In 2018, dengue infection attacked 210 persons, and one person died due the infection. Thus Kupang City was determined to have extraordinary incidents of dengue infection by the government.

Aim : This research was conducted to determine whether there is a relationship between larvae index and the behavior of eradicating mosquito nest with the incidence of dengue infection in the city of Kupang.

Method: This study used a cross-sectional design and data collection was carried out by random sampling with a total sample of 60 samples divided into three working areas of the health center and secondary data in the form of the incidence of dengue infections obtained from the health center in January-June 2019 period.

Results: there was a significant relationship between the behavior of eradicating mosquito nest with the incidence rate of dengue infection in Kupang City $(\mathrm{p}=0,006)$. A significant correlation between larva existence with the incidence rate of dengue infection $(p=0,006)$ and significant correlation between the behavior of eradicating mosquito with larva existence $(\mathrm{p}=0,000)$.
\end{abstract}

Conclusion: there is a significant relationship between the behavior of eradicating mosquito nests and larva existence with the incidence rate of dengue infection at Kupang City.

Keywords: dengue infection, outbreak, larvae index,mosquito breeding eradication behavior

1) Student of Faculty of Medicine, Widya Mandala Catholic University, Jl. Kalisari Selatan No.1 Surabaya. Email : juliodefatima2207@gmail.com

${ }^{2)}$ Public Health Medicine Department, Faculty of Medicine, Widya Mandala Catholic University Surabaya Jl. Kalisari Selatan No. 1 Surabaya

3) Parasitology Department, Faculty of Medicine, Widya Mandala Catholic University J1 Kalisari Selatan No 1 Surabaya 


\section{INTRODUCTION}

Indonesia is a country that is categorized as endemic of dengue infection. Dengue disease is a scourge for the community because it threatens patient safety. In 2019, on 29 January, based on data from the ministry of health Indonesia Republic, the total patient infected by dengue virus was 13.863 people, and 132 people died. East Nusa Tenggara Province was ranked third after East Java and Central Java according to the total patient that was infected by the dengue virus. ${ }^{1}$

The total case of dengue infection in East Nusa Tenggara Province, on 1 February 2019 based on data from the health authority in East Nusa Tenggara, was 1.337 cases. Kupang city was ranked second after West Manggarai with total 245 cases. This number was higher than the previous year, which was 66 cases. By this condition, the government of Kupang City declared that Kupang City is an area of extraordinary incident. ${ }^{2}$

Indonesia's government has declared a program known as $3 \mathrm{M}$ Plus to eradicate Aedes aegypti nests. The purpose is to achieve wiggler free numbers at the level of $95 \%$. The example of $3 \mathrm{M}$ Plus is 1) use abate powder at water containers, 2) use insect repellent, 3) use a mosquito net, 4) raising fish that eating Aedes aegypti larvae, 5) raising larvae eating plants, 6) make sure of proper lighting and ventilation in the house, 7) hanging clothes in wardrobe. ${ }^{3}$ This study examined the correlation between behavior of eradicating mosquito nests and larva index with incidence rate of dengue infection in Kupang City.

\section{METHOD}

This research used a cross-sectional method with a random sampling technique. Use 2 data, one was primary data, and the other was secondary data. Primary data was data by an interview with the respondent about behavior to eradicating mosquito nests. Secondary data was data about the total incidence rate of dengue infection at health center Oesapa, Kupang Kota, and Manutapen. The population of this research was people aged 17-60 years old. The sample in this research was 20 samples per health center, so the total sample was 60 samples for three health center. 


\section{RESULTS}

Table 1 showed a research result about subject characteristic. Table 1 showed that male has $10(17 \%)$ in number compared to female which has $50(83 \%)$

Table 1. Base Characteristic of Subject in This Research Based on Gender

\begin{tabular}{|c|c|c|}
\hline Gender & Total(n) & Percentage (\%) \\
\hline Male & 10 & 17 \\
\hline Female & 50 & 83 \\
\hline Total & 60 & 100 \\
\hline
\end{tabular}

Table 2 showed characteristic of subjects based on age. Respondent with age between 17 and 30 has 15 in total (25\%) compared to $83(75 \%)$ in age group between 31-60

Tabel 2. Base Characteristic of Subject in This Research Based on Age

\begin{tabular}{llccc}
\hline Age & Male & Female & Total & Percentage (\%) \\
\hline $17-30$ & 3 & 12 & 15 & 25 \\
\hline $31-60$ & 7 & 38 & 45 & 75 \\
\hline Total & 10 & 50 & 60 & 100 \\
\hline
\end{tabular}

\section{Behavior Scale in Health Center}

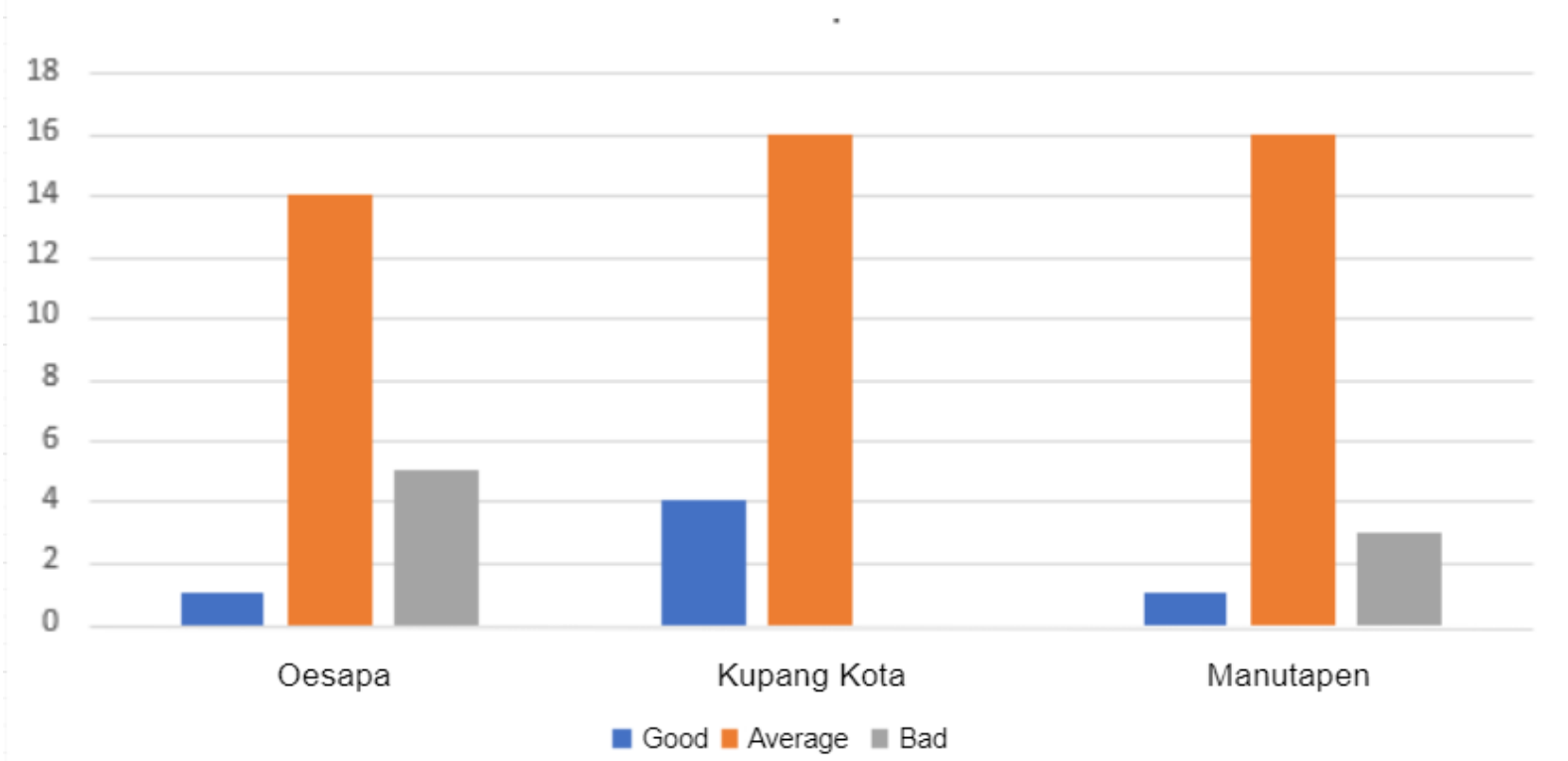

Figure 1. Characteristic of Behavior to Eradicating Mosquito Nests in 3 Puskesmas 


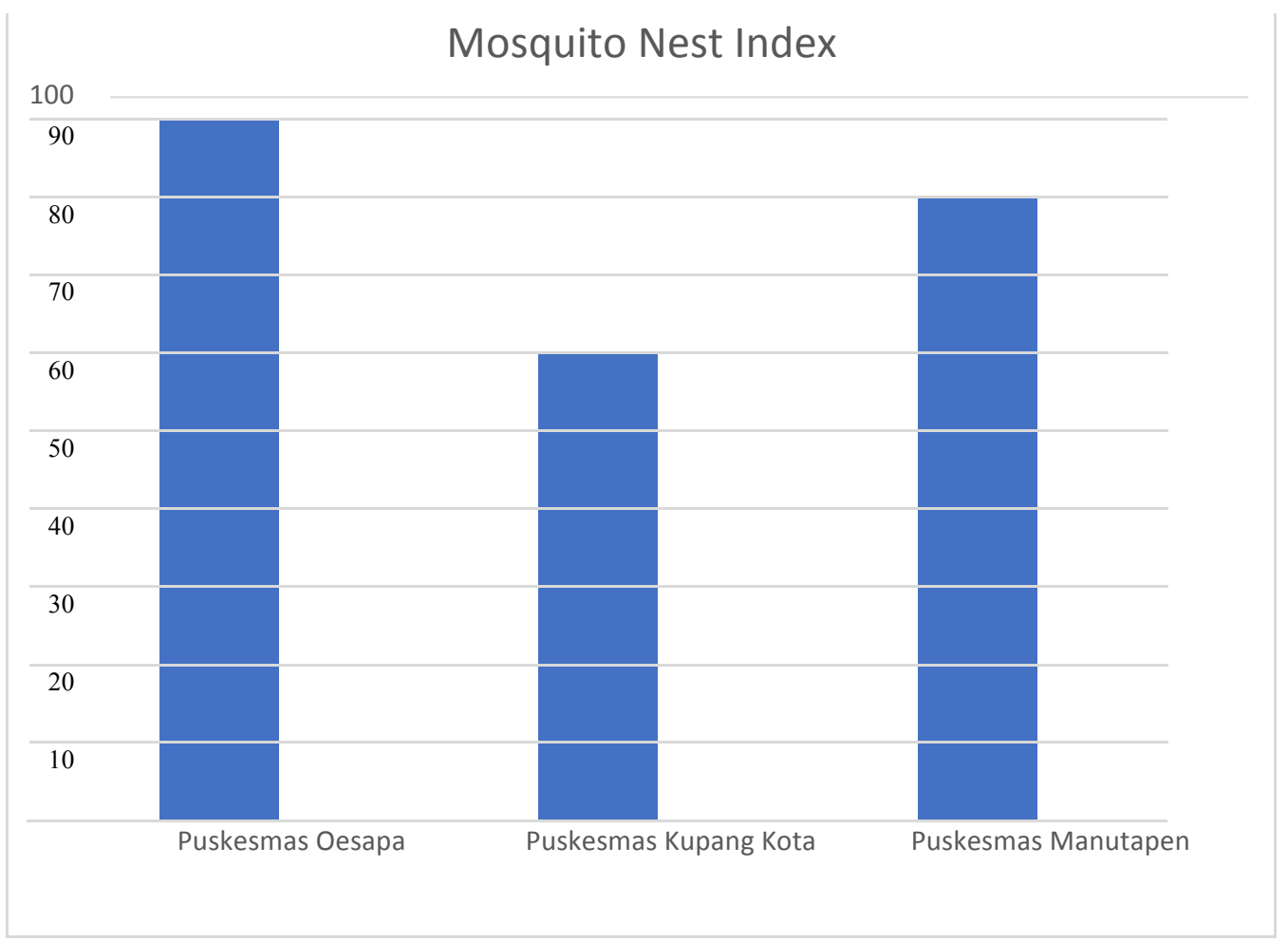

Figure 2. Characteristic of Larvae Index in 3 Puskesmas

\section{Incidence Rate}

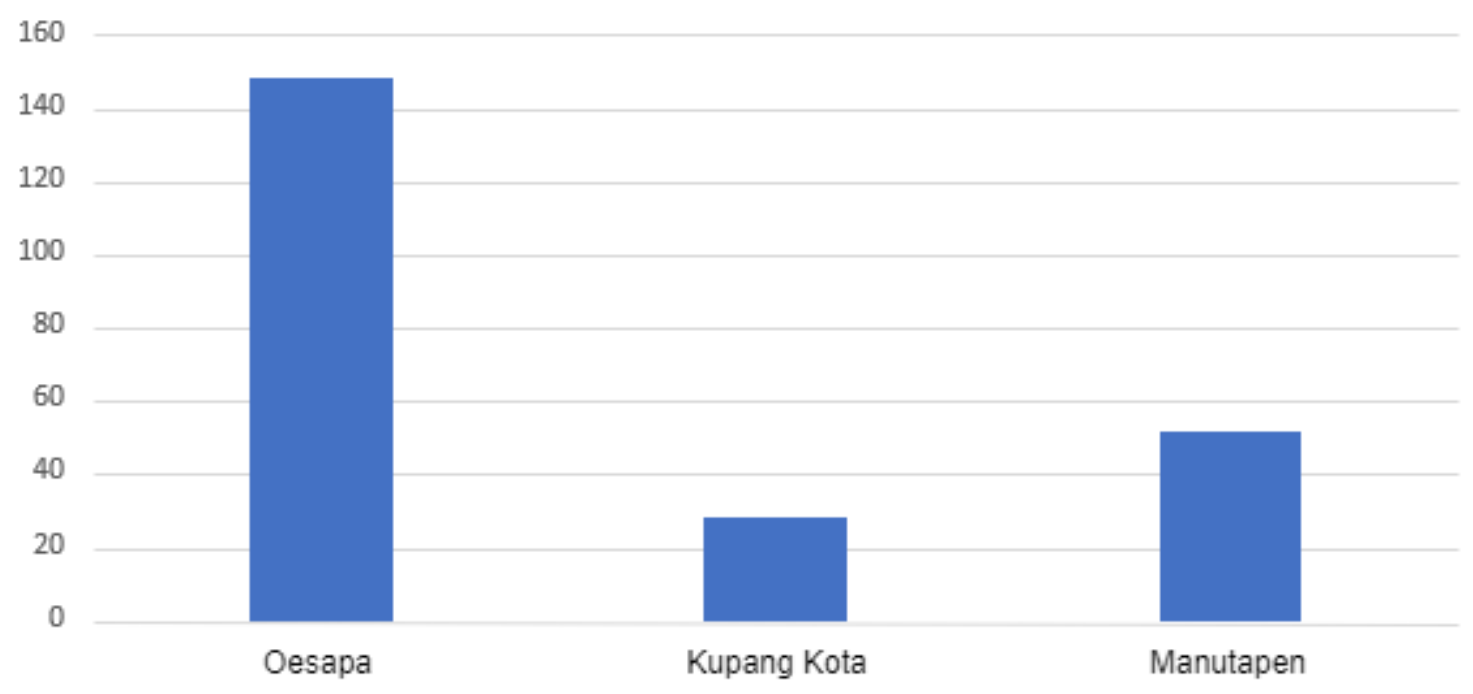

Figure 3. Characteristic of Insidens Rate dengue infection 
Tabel 3. The analysis result between behavior to eradicating mosquito nests and insidens rate

\begin{tabular}{|c|c|c|c|c|c|c|c|}
\hline \multirow[t]{3}{*}{ Variable } & \multicolumn{6}{|c|}{ Incidence rate } & \multirow[t]{3}{*}{$P$ value } \\
\hline & \multicolumn{2}{|c|}{ High } & \multicolumn{2}{|c|}{ Low } & \multicolumn{2}{|c|}{ Total } & \\
\hline & $\mathrm{n}$ & $\%$ & $\mathrm{n}$ & $\%$ & $\mathrm{n}$ & $\%$ & \\
\hline \multicolumn{8}{|l|}{ PSN } \\
\hline Good & 2 & 33,3 & 4 & 66,7 & 6 & 100 & 0,006 \\
\hline Avg & 30 & 65,2 & 16 & 34,8 & 46 & 100 & \\
\hline $\mathrm{Bad}$ & 8 & 100 & 0 & 0 & 8 & 100 & \\
\hline
\end{tabular}

Tabel 3 shows that between behavior to eradicating mosquito nests and incidens rate is significan with $\mathrm{P}$ value $=0,006$

Tabel 4. The analysis results between larvae and incidence rate

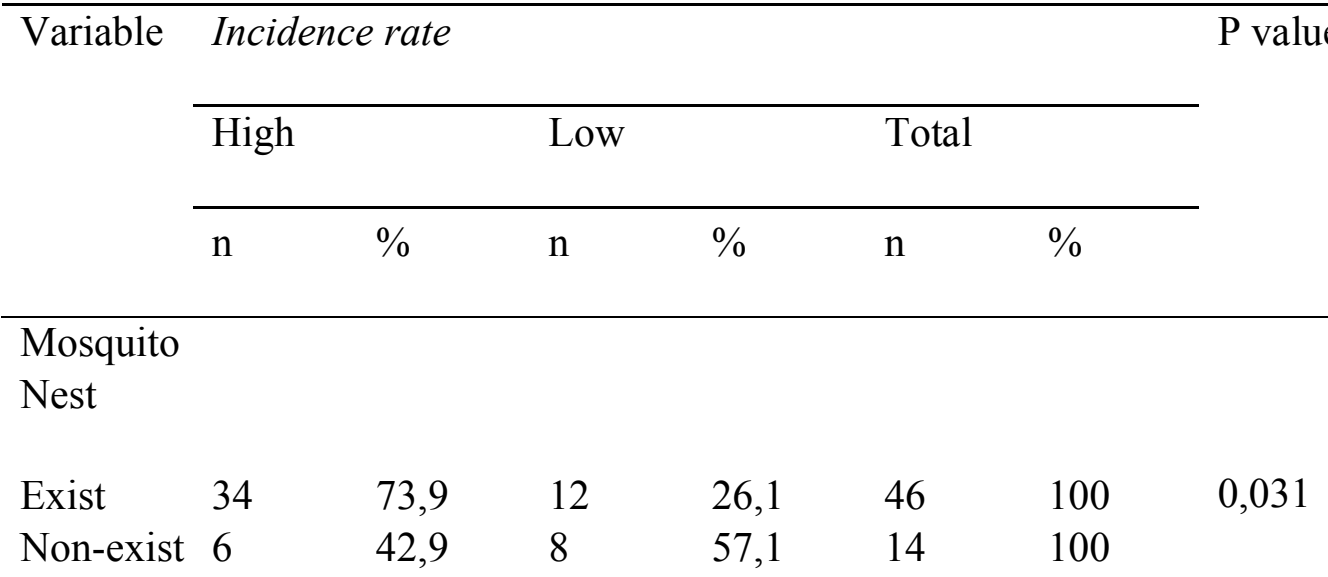

Tabel 5. The descriptive analysis results between larvae index and insidens rate

Health center Incidence Rate Mosquito Nest Index

\begin{tabular}{lll}
\hline Oesapa & 148,107 & 90
\end{tabular}

\begin{tabular}{lll}
\hline Kupang Kota & 51,840 & 80
\end{tabular}

$\begin{array}{lll}\text { Manutapen } & 28,920 & 60\end{array}$


Tabel 6. The analysis results between behavior to eradicating mosquito nests and larvae index

\begin{tabular}{|c|c|c|c|c|c|c|c|}
\hline \multirow[t]{3}{*}{ Variable } & \multicolumn{6}{|c|}{ Mosquito Nest Existence } & \multirow[t]{3}{*}{$P$ value } \\
\hline & \multicolumn{2}{|c|}{ Exist } & \multicolumn{2}{|c|}{ Non-Exist } & \multicolumn{2}{|c|}{ Total } & \\
\hline & $\mathrm{n}$ & $\%$ & $\mathrm{n}$ & $\%$ & $\mathrm{n}$ & $\%$ & \\
\hline \multicolumn{8}{|l|}{ PSN } \\
\hline Good & 0 & 0 & 6 & 100 & 6 & 100 & 0,000 \\
\hline Avg & 38 & 82,6 & 8 & 17,4 & 46 & 100 & \\
\hline $\mathrm{Bad}$ & 8 & 100 & 0 & 0 & 8 & 100 & \\
\hline
\end{tabular}

\section{DISCUSSION}

According to the results of this research, we found that the was significant. The good behavior such as using abate powder, draining and closing water containers like tub, drum, and former cans cause the Aedes aegypti unable to put their eggs. Reduced number of eggs causes the proliferation of Aedes aegypti from larvae to adult mosquito to diminished. The effect is the adult mosquito is diminished as an infectious vector of dengue infection. If the vector is lesser, the incidence rate of dengue infection can be reduced. ${ }^{4,5}$ This condition is the purpose of the $3 \mathrm{M}$ Plus program by the Indonesian government as a way to control dengue infection $3,7,8,9,10$.

\section{CONCLUSION}

This research that was done in JulyAugust 2019 at Puskesmas Oesapa, Kupang Kota and Manutapen, with total respondent 60 people showed significant correlation. This condition shows that the behavior of eradicating mosquito nests and larvae index affected incidence rate of dengue infection at Kupang City.

\section{REFERENCES}

1. Kesehatan D. Kasus DBD Terus Bertambah, Anung Imbau Masyarakat Maksimalkan

PSN[Internet].2019.Tersediapada:

https://www.google.com/url?sa=t\&rct= $\mathrm{j} \& \mathrm{q}=\&$ esrc $=\mathrm{s} \&$ source $=$ web $\& \mathrm{~cd}=1 \& \mathrm{ca}$ $\mathrm{d}=$ rja\&uact $=8 \&$ ved $=2$ ahUKEwi09vvC 6PbhAhWGv48KHS6XBUUQFjAAeg QIBRAB\&url

$=$ http $\% 3 \mathrm{~A} \% 2 \mathrm{~F} \% 2 \mathrm{Fwww}$.depkes.go.id 
\%2Farticle\%2Fview\%2F 19020600004

$\% 2$ Fkas us-dbd-terus-bertambahanung-imbau-masyarakat-maksimalka

2. Wismabrata MH. Fakta Kasus DBD di NTT. 19 Februari 2019;

3. RI K. Kejadian Demam Berdarah di Indonesia Tahun 2016. Dep Kesehat. 2016;

4. Brown H., NEVA.FA. Basic Clinical Parasitology. 6 th. Prentice Hall International

Edition; 1994. 227-228 hal.

5. James M, Hardwood R. Herm's Medical Entomology. 6th ed. The Macmillan Company USA; 1969. 150 hal.

6. SEMBEL D. Entomologi Kedokteran. ANDI Yogyakarta; 2009. 80-811 hal.

7. WHO. Global Strategy for Dengue Prevention and Control 2012-2020. World Health Organization [Internet] 2012 [cited 2017 Sep 28];43 Available from: www.who.int/neglected_disease s/en

8. Bhatt S, Gething PW, Brady OJ, Messina JP, Farlow AW, Moyes CL, et al. The global distribution and burden of dengue. Nature. 2013;496(7446):504-7. pmid:23563266; PubMed Central PMCID: PMC3651993.

9. Aryanti MR, Uiterwaal CS, Kusriastuti R, Hadinegoro SR, Rovers MM, Heesterbeek $\mathrm{H}$, et al. The changing incidence of dengue haemorrhagic fever in Indonesia: a 45-year registrybased analysis. BMC Infect Dis. 2014;14(1):412.

10. WHO SEARO. Comprehensive Guidelines for Prevention and Control of Dengue and Dengue Haemorrhagic Fever: WHO SEARO; 2011. 